\title{
Effects of the earthquake of September 19, 2017, in homes, in the municipality of Chietla, Puebla
}

\section{Efectos del terremoto del 19 de septiembre de 2017, en viviendas, en el municipio de Chietla, Puebla}

VÁZQUEZ-TORRES, María del Rayo $\dagger^{*}$, CASTILLO-REYES, Alberto Rosendo, MORALESORTEGA, José Alejandro and MONTERO-URRUSQUIETA, Rubén Ángel

Benemérita Universidad Autónoma de Puebla, Mexico.

ID $1^{\text {st }}$ Author: María del Rayo, Vázquez-Torres / ORC ID: 0000-0002-3509-2684, Researcher ID Thomson: U-85612018, CVU CONACYT ID: 508248

ID $1^{\text {st }}$ Co-author: Alberto Rosendo, Castillo-Reyes / ORC ID: 0000-0001-6338-2534, Researcher ID Thomson: U-94402018, CVU CONACYT ID: 950754

ID $2^{\text {nd }}$ Co-author: José Alejandro, Morales-Ortega / ORC ID: 0000-0001-8379-4405, CVU CONACYT ID: 659620

ID $3^{\text {rd }}$ Co-author: Rubén Ángel, Montero-Urrusquieta / ORC ID: 0000-0001-6325-2238, CVU CONACYT ID: 599097

DOI: $10.35429 /$ EJS.2021.15.8.16.26

Received July 25, 2021; Accepted December 30, 2021

\section{Abstract}

This work aims to publicize the effects of the 2017 earthquake on homes in the municipality of Chietla, Puebla, epicenter of the earthquake. The fieldwork was carried out by teachers and students of the Faculty of Architecture of the Benemérita Universidad Autónoma de Puebla, to support the community with a damage survey. To carry out the work, a report sheet was used where the data from the survey sheet were processed, determining the seismic analysis, the state of the construction was verified. The working groups were composed of a teacher and four students who visited each house, where images were taken, the location by latitude and longitude coordinates and the data collection. Subsequently, the information was gathered and a report was made to Civil Protection ranking the degrees of affectation. This work is the result of this field research divided into three sections. In the first part, the concepts involved in the topic are defined; the second part describes the geographical location and characteristics of Chietla; finally, the third part identifies the most common faults found in the fieldwork.

Earthquake, Vulnerability, Failures

\section{Resumen}

Este trabajo tiene como objetivo dar a conocer los efectos del terremoto de 2017 en las viviendas del municipio de Chietla, Puebla, epicentro del terremoto. El trabajo de campo fue realizado por docentes y estudiantes de la Facultad de Arquitectura de la Benemérita Universidad Autónoma de Puebla, para apoyar a la comunidad con una encuesta de daños. Para realizar el trabajo se utilizó una hoja de informe donde se procesaron los datos de la hoja de levantamiento, determinando el análisis sísmico, se verificó el estado de la construcción. Los grupos de trabajo estuvieron compuestos por un docente y cuatro alumnos que visitaron cada casa, donde se tomaron imágenes, la ubicación por coordenadas de latitud y longitud y la recolección de datos. Posteriormente, se recabó la información y se elaboró un informe a Protección Civil ordenando los grados de afectación. Este trabajo es el resultado de esta investigación de campo dividida en tres secciones. En la primera parte se definen los conceptos involucrados en el tema; la segunda describe la ubicación geográfica y las características de Chietla; finalmente, la tercera parte identifica las fallas más comunes encontradas en el trabajo de campo.

Terremoto, Vulnerabilidad, Fallos

Citation: VÁZQUEZ-TORRES, María del Rayo, CASTILLO-REYES, Alberto Rosendo, MORALES-ORTEGA, José Alejandro and MONTERO-URRUSQUIETA, Rubén Ángel. Effects of the earthquake of September 19, 2017, in homes, in the municipality of Chietla, Puebla. ECORFAN Journal-Spain. 2021. 8-15:16-26.

\footnotetext{
* Correspondence to Author (Email: mrayo.vazquez@correo.buap.mx)

$\dagger$ Researcher contributing first author.
} 


\section{Introduction}

Buildings constantly show structural damage so small that they go unnoticed, others are more evident, but those that do not put their inhabitants at risk are considered minor damage; but there are other serious damages that can be caused by poor structuring or be caused by intense seismic movements.

The task of the architect in Mexico is to design, build, budget, rethink architectural proposals to adapt them to the needs of the current era and assess the conditions of the buildings, among other tasks. Every architectural process raises different questions and different answers for the same problem or project. In the academic field, the teacher has to constantly prepare to give guidance to his students and at the same time carry out research activities and support to the community.

It is for these reasons that such important phenomena as the sismos occur, an immediate technical response must be given because if we do not do so, people's lives are being exposed and it would be irresponsible not to do so. Therefore, public universities such as the Benemérita University of Puebla are obliged to support communities that experienced serious situations.

The Benemérita University of Puebla, BUAP, supporting the government of the State of Puebla with the collaboration of the faculty of engineering and architecture organized brigades for the analysis of housing in areas that required technical support. Therefore, a group of professors of the faculty of architecture were assigned Chietla for the review and analysis of the houses, whose evaluations allowed to determine the security that there would be no need to fear before possible aftershocks of the earthquake or the risk that the inhabitants of some houses ran.

In the work of brigades there was the work of authorities, teachers and students of the faculty of architecture who not only focused on giving a technical response, but also a human approach where users exposed their problems because they needed to be heard and guided. In this practice, the students found themselves in the possibility of supporting and learning from the effects that housing had and understanding how to improve their professional practice. Also, it was found that the inhabitants were in solidarity with each other, because, if they did not need food or economic aid; they rejected them because others had difficult living conditions and were not going to deprive them of the help that was given to them at that time.
It stands out in the case of the groups of students the enthusiasm to allow them to help and at the same time learn things that they only see in theory and that made them aware of the importance of knowledge and ethics because they become responsible for the safety of users. In the case of the teachers, they were allowed to help and learn from the students because they used digital applications that facilitated the work of localization, becoming an amalgam that allowed them to deliver a professional work. As for the Institution, the organization was efficient, fulfilling its humanist approach. Regarding the knowledge obtained, it could be noted that the vernacular houses did not have serious problems because in the area there is a constructive tradition that allowed to elaborate houses with good quality. The problems arose in buildings with old and humid materials due to the constant rains of the previous two weeks and in new homes where the structural elements were not correctly located or modifications were made without considering the nature of the house.

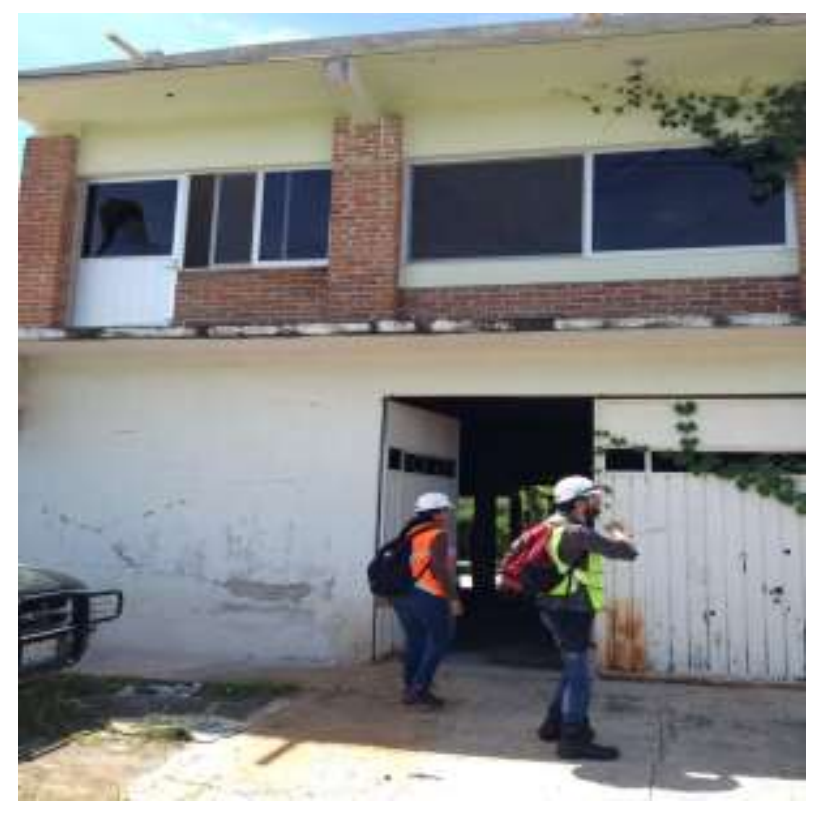

Figure 1 Buap students

Source: Faculty of Architecture BUAP, 2017

During the work of field research and community support was considered the methodology of civil protection that also mention Espada, Mego, Quevedo, Barreto, \& Naupari (2021). This consisted of a preliminary evaluation where a visual inspection of the house was made to observe and describe the conditions of the house, considering the local faults and the physical conditions of the environment. At this stage, the areas or structural elements that presented damage were delimited and identified according to their levels of affectation. The record of the conditions found was applied the format of civil protection for lifting of damages.

VÁZQUEZ-TORRES, María del Rayo, CASTILLO-REYES, Alberto Rosendo, MORALES-ORTEGA, José Alejandro and MONTERO-URRUSQUIETA, Rubén Ángel. Effects of the earthquake of September 19, 2017, in homes, in the municipality of Chietla, Puebla. ECORFAN Journal-Spain. 2021 
The civil protection format considers the type of natural phenomena that generate the damage; types of structure in building in vertical elements (columns and walls) and horizontal elements (Locks and slabs); types of damage to building structures; building sketch and damage record; elaboration of sketches of the building structure and registration of the damage.

In the concept of types of structure in building in vertical and horizontal elements are recorded the physical conditions of the house and its environment as cracks in multiple supports, high deflections in roofs, notable differential settlements, lack of coating in reinforcing steels, colorations in the structural elements that can be a sign of corrosion, areas with high humidity, exposure to salts, chlorides, etc. Also, there are problems of corrosion or aggression to the concrete and the degree of exposure to these substances and / or conditions. It is important to describe the quantitative elements such as the bearing capacity of the house, angles of turning of the supports, measurement of fissures, width of cracks. In the case of the structural characteristics of the house, exposure to sulfates and the removal or addition of some structural element must be recorded. at the time of any remodeling in the house. Espada, Mego, Quevedo, Barreto, \& Naupari (2021).

This work was done to rank and classify the type of damage and identify the most serious cases that could pose a danger to the lives of users, which, if it happened and people had to vacate the houses to allow their intervention.

It should be noted that the homes that had problems during and after the 2017 earthquake were due to the fact that the materials were very old, had no maintenance or had interventions that damaged the house. That is, few cases were due to bad practice because the community has a constructive tradition that has allowed their homes to withstand the actions of the sismos.

According to Espada, Mego, Quevedo, Barreto, \& Naupari (2021) the useful life of a building is the period from the moment the building is used until a major intervention is necessary to allow its use, without danger to its inhabitants. The period included for an important intervention in the building can reach 40 years or 70 years, where the design earthquake that causes the structure to enter the inelastic range that is the maximum tension that a material supports without suffering permanent deformations will occur.
For Silva (2021), the vernacular house of Mexico has been designed and built to meet the bioclimatic comfort and by the use of the materials of the area the integration with the environment occurs. However, this close relationship has been broken because industrialized materials are used that modify that environment, although in the last three decades of the twentieth century the concept of sustainability is integrated into architecture with countless works carried out by the country's universities. There are two currents on ecotechnologies for housing that are: technology such as photovoltaic cells, solar heaters, water saving devices, boiler of passage, films and thermal insulators, among others and the non-technified ones that are built with materials from the area or easy to acquire.

The population cannot access the technological systems due to their high costs, but it was observed that some houses that were visited have rainwater harvesting systems, dry baths, compost and solar stoves. On the other hand, the population does not have access to new housing financing, whose institution annually finances around 350,000 homes with a Green Mortgage in the country, so that the inhabitants acquire used homes or use selfconstruction. This means that some homes lack quality and cannot be resistant to the action of the sismos as observed in the visits to the community.

\section{Earthquake}

Sismos are movements of the earth, caused by the release of energy in the form of waves, due to the collision of tectonic plates, causing the Earth's crust to slide along a fault. (Carhuanira, 2021)

An earthquake can be defined as the propagation of waves through the Earth's environment that produce vibration; the propagation of seismic waves that cause damage is of three basic types of which two are internal because they propagate in all directions in the interior of the Earth and the primary wave or $\mathrm{P}$ wave that is the fastest between 1,100 and $8,000 \mathrm{~m} / \mathrm{s}$. (CENAPRED 2011).

Tremors are the effect of a disturbance that occurs either on the surface or in the interior of the Earth and originates from movement, friction and deformation of tectonic plates; where frictional motion provides energy and is an important precursor to the quake, plate deformation stores that energy.

VÁZQUEZ-TORRES, María del Rayo, CASTILLO-REYES, Alberto Rosendo, MORALES-ORTEGA, José Alejandro and MONTERO-URRUSQUIETA, Rubén Ángel. Effects of the earthquake of September 19, 2017, in homes, in the municipality of Chietla, Puebla. ECORFAN Journal-Spain. 2021 
To understand what an earthquake is, it is necessary to understand the operation of tectonic plates. The core of planet Earth is made up of iron and nickel; the mantle is the middle part of the Earth, which is made up of ferromagnesian silicates. Finally, the outer part of the Earth called the lithosphere, is formed by the crust and part of the mantle with a thickness up to $100 \mathrm{~km}$. The lithosphere has a behavior similar to a rigid body that floats and moves according to the slow internal movement of the mantle; this movement is produced by convection currents because of the temperature difference between the region near the core. This internal movement of the mantle causes the Earth's lithosphere to be formed by different segments or lithospheric plates, or tectonic plates. The Mexican Republic consists of five tectonic plates: Pacific, North America, Caribbean, Rivera and Cocos. The Tectonic Plate of Cocos is the most important because there originates the greatest seismicity located on the coasts of the Mexican Pacific. In northern Mexico, the Pacific and North American plates have great friction; because the Pacific plate moves in a northwesterly direction and the North America plate moves to the southeast: while the Baja California peninsula is slowly moving away from the continent, it is a region of great seismic activity, product of almost vertical faults and move horizontally in opposite directions (Espíndola and Pérez, 2018).

It should be clarified that the terms earthquake, earthquake and tremor are synonymous and there are 3 types of natural earthquakes which are: tectonics are produced by interaction of 5 tectonic plates: The North American plate, the Cocos plate, the Pacific plate, the Rivera plate and the Caribbean plate, volcanic are produced by volcanic eruptions; and collapse of the roof of caverns or mines. The National Seismological Service reports on average the occurrence of 40 earthquakes per day by the 5 tectonic plates.

On September 19, 2017, the National Seismological Service (SSN) reported an earthquake with magnitude 7.1 located on the state border between the states of Puebla and Morelos, $12 \mathrm{~km}$ southeast of Axochiapan, Morelos and $120 \mathrm{~km}$ from Mexico City with six aftershocks until 18:00 hours on September 19. Aftershocks occur after a large earthquake and rocks near the rupture zone are rearranged causing tremors that vary the number of events that occur in several days or weeks.

\section{The site}

Puebla is located southeast of Mexico City, has 217 municipalities the second state with the largest number of municipalities; being the first Oaxaca and has seven geoeconomic regions. Within these municipalities is Chietla is located in the southwest of the State of Puebla bordering to the north with the municipality of Tepexco, to the south with the municipality of Chiautla de Tapia, to the west with the municipalities of Tilapa, Atzala and Izúcar de Matamoros, and to the west with the state of Morelos. The name of Chietla is defined by the Nahuatl words Chichic, cosa amarga and Tlán, together or near; that together they mean "Near the bitter thing"; its name originates from the date palms that existed in the region, which secrete a bitter saline. Chietla is located almost entirely in the sub-basin of the Nexapa River, a tributary of the Atoyac, which is the border with the State of Morelos that runs through the center of the municipality with irrigation branches that reach the valleys. It is a municipality with warm humid climate in almost the entire municipality and sub-humid warm climate in the southeastern mountains.

Chietla in 2017 became the epicenter of the quake; Carhuanira, (2021) defines the epicenter as the point located on the earth's surface in the vertical line of the focus or hypocenter, where the earthquake acquires its maximum intensity or degree of the effects caused by an earthquake. Magnitude is the energy with which an earthquake manifests itself, the Richter scale that goes from 0-10 and is obtained with instruments called seismographs. Vulnerability is the degree of exposure or fragility to the occurrence of a hazard.

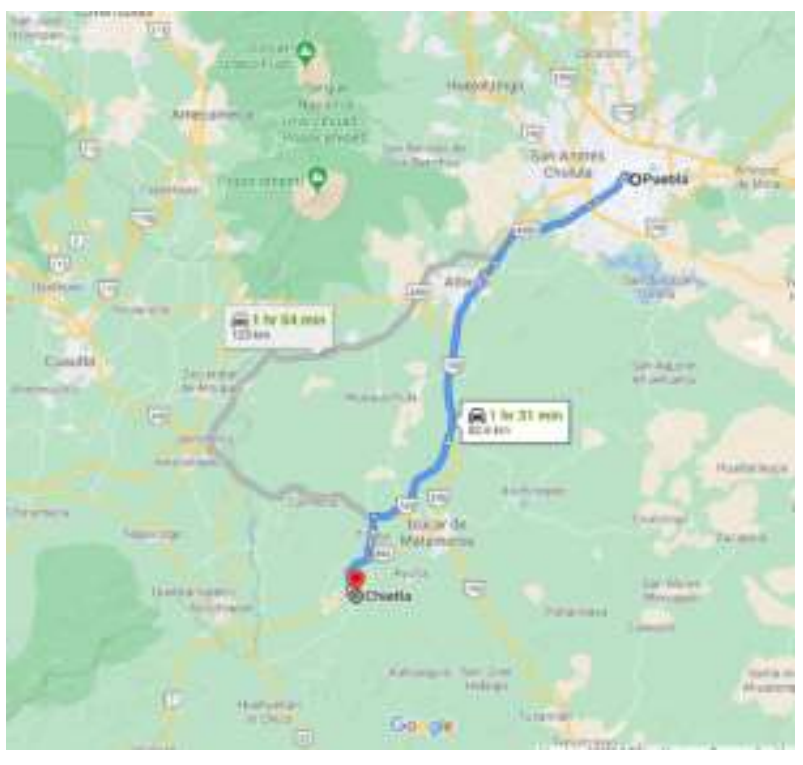

Figure 2 Location of Chietla

Source: Google maps, 2020
VÁZQUEZ-TORRES, María del Rayo, CASTILLO-REYES, Alberto Rosendo, MORALES-ORTEGA, José Alejandro and MONTERO-URRUSQUIETA, Rubén Ángel. Effects of the earthquake of September 19, 2017, in homes, in the municipality of Chietla, Puebla. ECORFAN Journal-Spain. 2021 
As for the population, after the earthquake was in a state of stress, for López, Muñoz, \& Visoso (2021), the post-traumatic stress that caused the earthquake of September 19, 2017, the main feelings evidenced by the population are fear, uncertainty and stress. These feelings are more intense in adults than in children and adolescents. People are unexpectedly subjected to natural disasters and their consequences.

However, it was observed that the inhabitants know this type of experience and even know the technical language; because according to them they have had to deal with that reality constantly and have been supported by the Universities to understand the dangers to which they are subject. They also met people who commented that the quake had not been as intense and that nothing had actually happened.

López, Muñoz, \& Visoso (2021), distinguish two types of strategies in a demanding situation: problem-solving strategies or direct action where information is sought, strategies for anticipating a disaster, control of oneself and circumstances and social support and strategies for regulating emotions where the person can range from denial to behaviors of rejection and passive acceptance.

Also, these authors mention that the psychological consequences after disasters are diverse with symptoms such as reexperimentation of the event either expressed in nightmares or constant and involuntary images, denial or difficulties in concentrating, generalized distress, agitation, tremor, sleep disorders with variable durations that produce physiological effects. Sismos are seen as a threat to life and can have an effect on protective behaviors, forms of individual and collective adaptation. This situation contributes to families, fearing a new seismic event, resorting to reinforcing their homes or abandoning the traditional construction system because they consider it inefficient to withstand natural threats.

The State Commission for Reconstruction, earthquake report September 19, 2017 of the 217 municipalities of the state of Puebla, 112 were declared in emergency situation and 9 command centers were generated. The command center of Izúcar de Matamoros contemplated the municipalities of Acteopan, Ahuatlán, Atzala, Chietla, Coatzingo, Cohuecán, Epatlán, Izúcar de Matamoros, San Martín Totoltepec, Teopantlán, Tepemaxalco, Tepeojuma, Tepexco, Tilapa, Tlapanalá, Xochiltepec.
The 2017 Puebla earthquake occurred at 1:14:40 p.m. local time on Tuesday, September 19 with a magnitude of $7.1 \mathrm{Mw}$. Whose epicenter was located $12 \mathrm{~km}$ southeast of Axochiapan, Morelos. Earthquakes ..." They are sudden movements of the Earth's crust, originated by the release of accumulated energy, mainly in the faults or fractures of the plates, resulting in landslides that define the magnitude of the earthquake" (Government of the State of Puebla 2019).

The Mexican geological survey classifies the sismos as follows: tectonic sismos (interaction of tectonic plates); volcanic sismos (fracture of rocks by movements of magma and released by a volcanic eruption); collapse quaes (collapses of caverns and mines); artificial (man-made) sisms; deep sismos (generated at a depth of more than $75 \mathrm{~km}$ ); cortical sismos (occurring superficially less than $75 \mathrm{~km}$ deep); interplate sismos (produced in the limits between two tectonic plates) and intraplate sismos (produced within a tectonic plate) (Government of the State of Puebla 2019).

According to the Government of the state of Puebla, in the Special Program for Seismic Emergencies (2018), it classifies the Mexican Republic, it was divided into 4 types of seismic zones to facilitate the anti-seismic design of the facilities of the Federal Electricity Commission (CFE). The following describes:

Zone A (there are no historical records of sismos in the last 80 years); zones $\mathrm{B}$ and $\mathrm{C}$ are intermediate zones (not so frequently occurring sismos or are areas affected by high accelerations without exceeding $70 \%$ of the ground acceleration) and zone D (large frequent historical axes and with soil accelerations that can exceed $70 \%$ of the acceleration of gravity). The state of Puebla belongs to zone B, which in turn divides the state into three seismic risk zones: High Risk where epicenters are frequent and includes municipalities such as Tehuacán, Acatlán, Izúcar de Matamoros and other nearby towns. Medium risk whose epicenters are less frequent and cover municipalities such as San Martín Texmelucan, Cholula, Puebla, Oriental, Lara Grajales, Ciudad Serdán, Tecamachalco, Acatzingo, Atlixco, and others of lower incidence. Low risk where epicenters are rare and are located the northern and northeastern sierra, cuetzalan region, Teziutlán and Zacatlán.
VÁZQUEZ-TORRES, María del Rayo, CASTILLO-REYES, Alberto Rosendo, MORALES-ORTEGA, José Alejandro and MONTERO-URRUSQUIETA, Rubén Ángel. Effects of the earthquake of September 19,2017, in homes, in the municipality of Chietla, Puebla. ECORFAN Journal-Spain. 2021 
The earthquakes that occurred in September 2017 caused serious damage to buildings and human losses because in the case of the state of Puebla 570 people died. In the case of hydrometeorological phenomena they represent more than $90 \%$ of the impact of disasters, however, in 2017 those of geological origin exceeded this proportion with $92.3 \%$ of the total damage and losses, mainly due to the September sismos. (Secretariat of Security and Citizen Protection and CENAPRED, 2017).

These hydrometeorological phenomena that the damage caused by the earthquake intensified causing in the affected municipalities by the constant concern that more earthquakes would happen that destroyed their homes due to structural vulnerability.

\section{The vulnerability of housing}

Structural vulnerability refers to exposure to possible damage to structural elements and nonstructural vulnerability is the fragility or exposure to possible damage of non-structural elements of the structure. In the case of traditional housing the concept of confined masonry is identified is a set formed by masonry and reinforced at the ends by mooring supports and at the top joined with concrete enclosures. As for the non-reinforced or unreinforced masonry also called Simple or factory masonry. (Carhuanira, 2021)

The structural vulnerability is defined according to the WHO, 2000 to the susceptibility that the structure presents to possible damage to the elements that allow the construction to continue standing before an intense earthquake such as the one that occurred on September 19, 2017.

It is important to point out the concepts that will be used, according to Carhuanira (2021), which are the following:

The confined masonry is a structural system, formed by walls contained in units or blocks with reinforced concrete porticoes, which allow to resist the horizontal forces caused by a seismic movement, where symmetry, regularity in plant and height are sought. The most common damages in homes according to CENAPRED (2018) are: collapse of walls either in supporting elements or parapets, beams displaced by not being well attached to the wall or because these caused damage to the walls during the seismic movement, vertical and diagonal cracks in walls, long collapsed walls, vertical crack in corners, and inclined cracks in corner displacement enclosures (image 3).

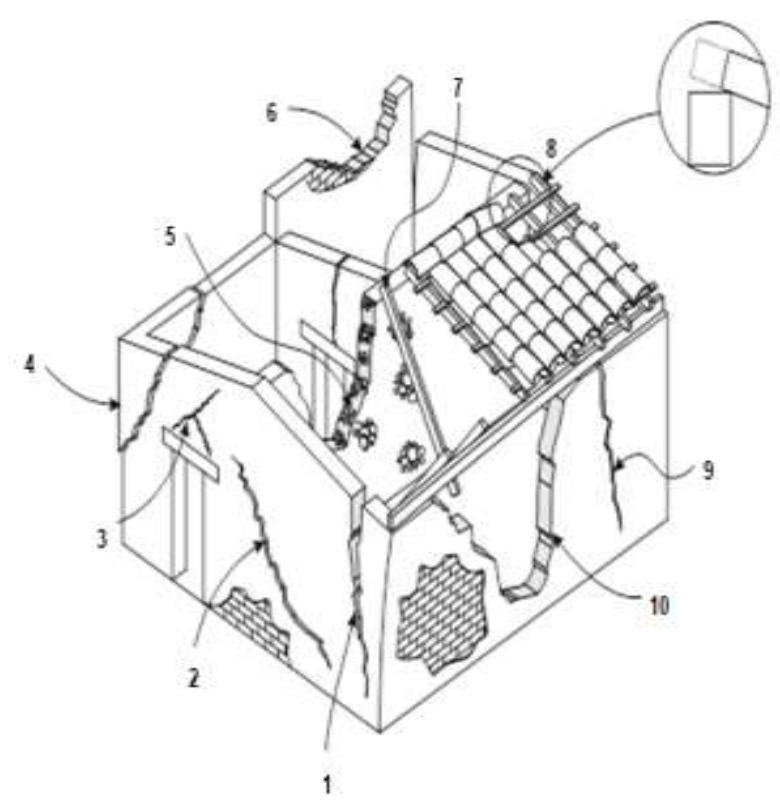

Figure 3 Common damage to adobe homes. 1. Vertical crack in corners by flipping walls. 2. Sloping cracks in walls. 3. Sloping cracks in enclosures. 4. Dislocation of corners. 5. Collapse of stone and mud walls. 6. Fallen parapet. 7. Fallen roof. 8. Beams run about to fall. 9. Vertical cracks in walls. 10 central turning on long walls Source: (CENAPRED, 2018)

This type of faults are manifested in the cracks, they are caused to the forces by torsion, tension and compression, movements that the sismos, with their types of movement that are oscillatory and trepidatory, and not being the buildings with a quality of construction both in labor and in the materials, are subject to present this type of cracks.

The most common types of faults in adobe buildings are as follows: bending perpendicular to the plane of the wall; bending perpendicular to the plane of the wall with vertical cracking in the central area; bending perpendicular to the plane at the unconfined corners of walls; Fall of the roof towards the interior of the house, for being badly supported on the walls; poor connection of the walls of the first floor with those of the second.

Bending perpendicular to the plane of the wall. Horizontal cracking at the base or at an intermediate height and additional vertical cracks. When the wall is subjected to an acceleration, the inertial forces of the distributed mass of the wall cause the wall to deform in double curvature outside the plane; most inertial forces are transmitted to the sides of it. (Jaramillo, 2002).
VÁZQUEZ-TORRES, María del Rayo, CASTILLO-REYES, Alberto Rosendo, MORALES-ORTEGA, José Alejandro and MONTERO-URRUSQUIETA, Rubén Ángel. Effects of the earthquake of September 19, 2017, in homes, in the municipality of Chietla, Puebla. ECORFAN Journal-Spain. 2021 


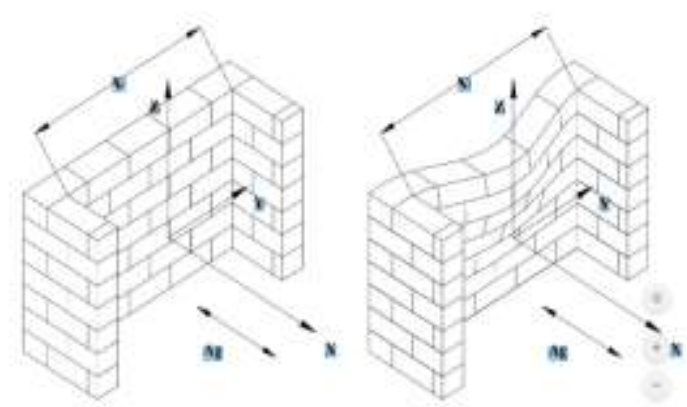

Figure 4 Orientation of the wall with respect to the acceleration at the base and deformation of it. It shows the orientation of the wall under study with respect to the requesting acceleration and the reference axes, $\mathrm{X}, \mathrm{Y}$ and $\mathrm{Z}$ that indicate: the direction perpendicular to the plane of the wall, the horizontal direction along the wall and the vertical direction, respectively. X Y Z L Ag X L Z Y

Source: Jaramillo, 2002

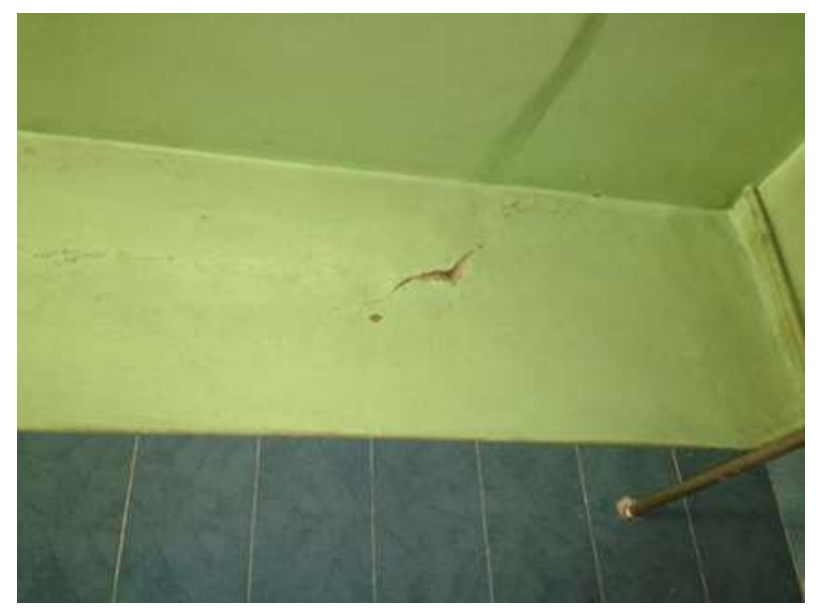

Figure 5 Bathroom of a house where the bending perpendicular to the plane of the adobe wall is shown Source: Faculty of Architecture BUAP, 2017

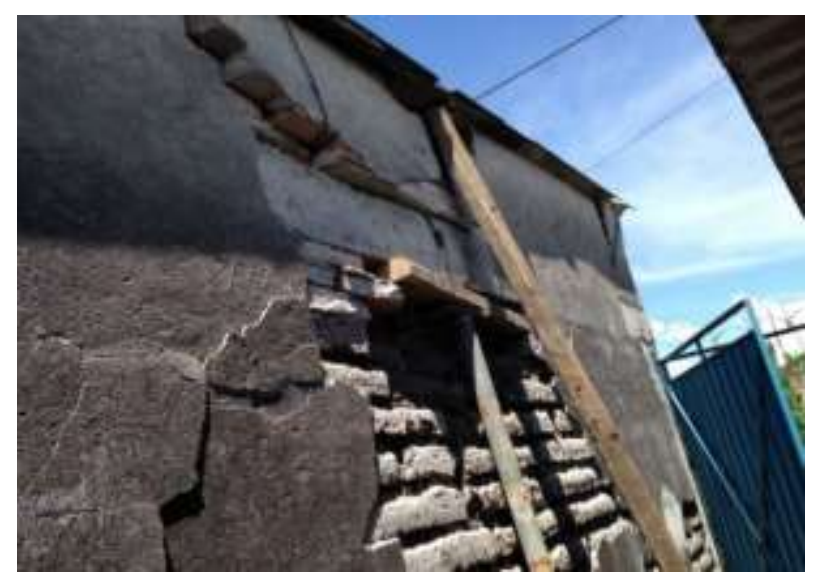

Figure 6 housing where the bending perpendicular to the plane of the adobe wall intensified by the structural failure of the enclosure is shown because the confined wall is not found and there is no effective distribution of the loads

Source: Faculty of Architecture BUAP, 2017

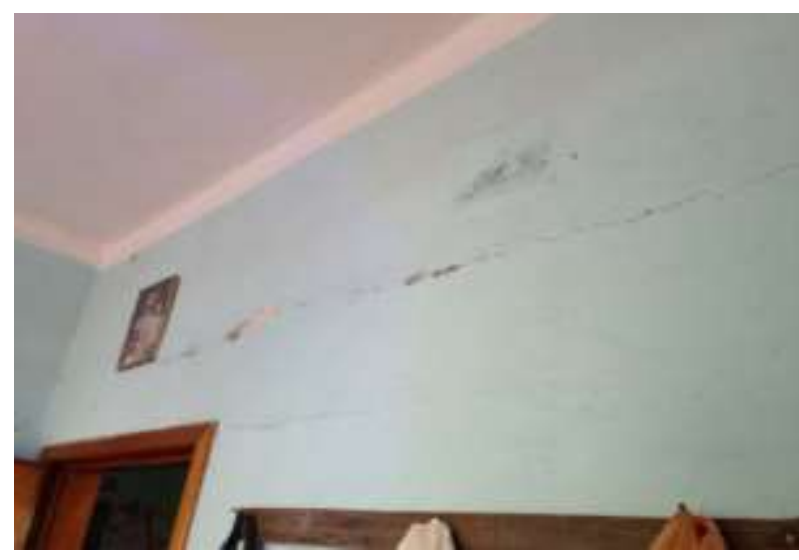

Figure 7 The longitudinal fault is seen in the image at the top

Source: Faculty of Architecture BUAP, 2017

It fails by bending perpendicular to the plane of the wall with vertical cracking in the central area. Diagonal cracking that constitutes the mechanism of failure and cracking at the top. The off-plane behavior of confined walls is different from that of unreinored, reinforced, and diaphragm walls. This is because the confined walls consist of an unreinsisted masonry panel and confining elements that form a flexible reinforced concrete frame. Diaphragm walls consist of a reinforced or nonreinforced masonry panel and a reinforced concrete or structural steel frame; in the case of diaphragm walls, first the frame is built and then the masonry panel, there being clearances between the frame and the masonry panel. (Varela, Chan, Fernández and Moreno, 2015).

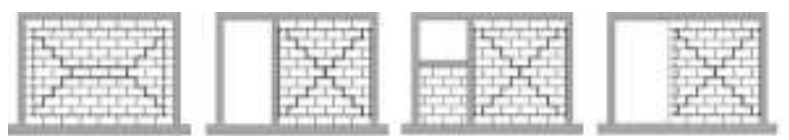

Figure 8 Main cracking pattern of the walls Source: (Varela, Chan, Fernández and Moreno, 2015)

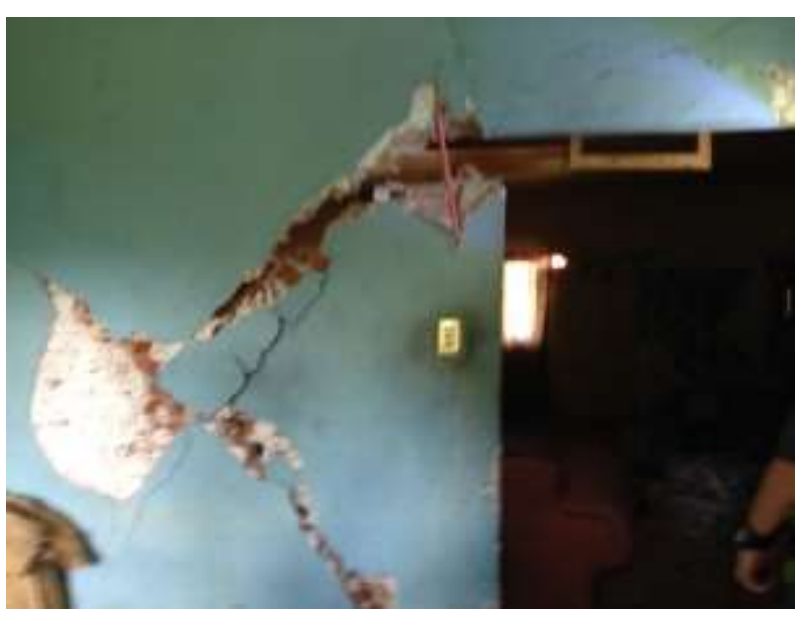

Figure 9 It fails by bending perpendicular to the plane of the wall by crushing the segments of the wall generating compression forces that increased until they reached the axial compression resistance of the masonry Source: Faculty of Architecture BUAP, 2017
VÁZQUEZ-TORRES, María del Rayo, CASTILLO-REYES, Alberto Rosendo, MORALES-ORTEGA, José Alejandro and MONTERO-URRUSQUIETA, Rubén Ángel. Effects of the earthquake of September 19,2017, in homes, in the municipality of 


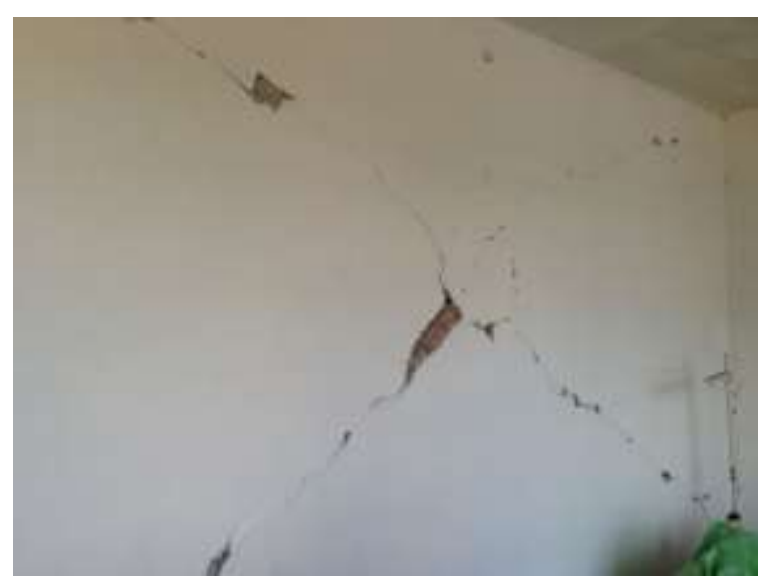

Figure 10 It fails by bending perpendicular to the plane of the wall by static instability of the segments caused by the rigidity of the upper dala

Source: Faculty of Architecture BUAP, 2017

Bending fault perpendicular to the plane at the unconfined corners of loose walls or at corners not effectively connected to the transverse walls. This problem is common when masonry acts independently and not being joined easily detaches causing the loss of verticality or collapse.

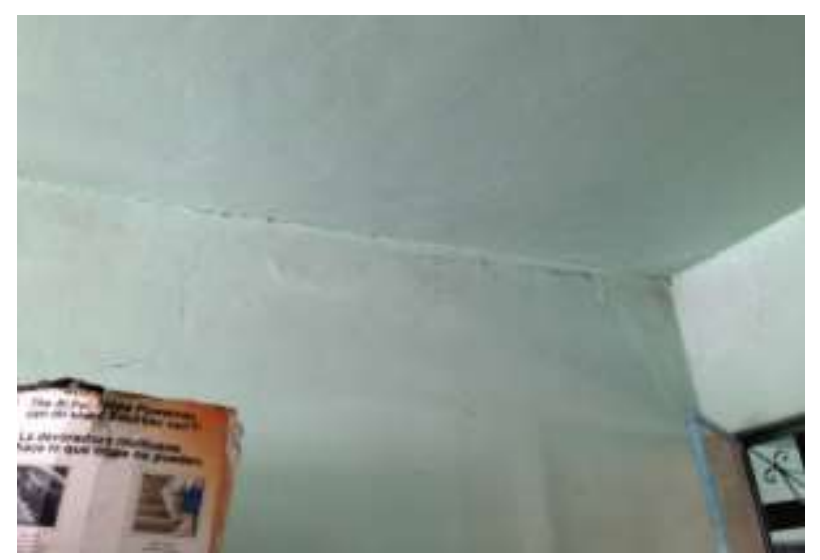

Figure 11 Unconfined walls, observed at the top of the wall, the separation of the wall with the roof

Source: Faculty of Architecture BUAP, 2017

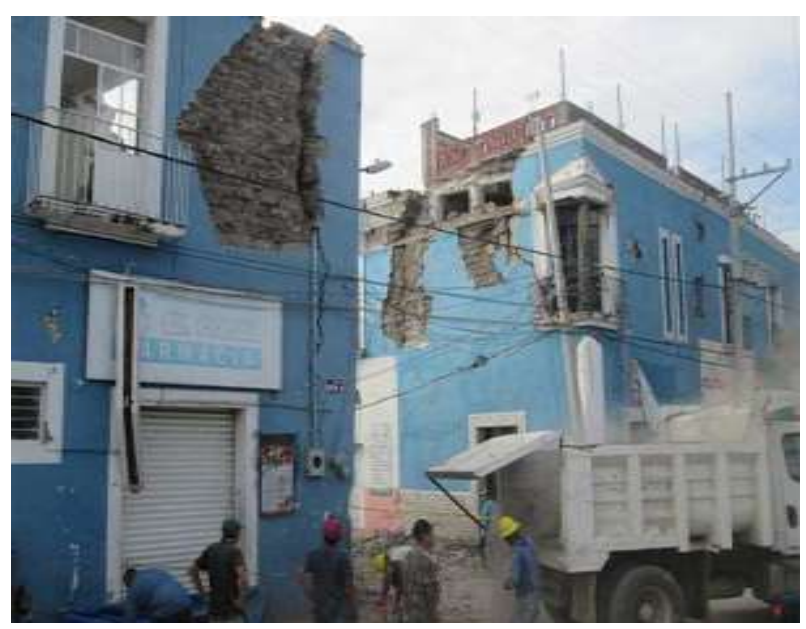

Figure 12 Unconfined walls, observed at the top of the wall, the separation of the wall with the roof Source: Cano, 2020
Fall of the roof towards the interior of the house, for being badly supported on the walls. A fault is generated in the upper area of the walls. This type of failure occurred in homes in the historic center of Chietla. Fault that arises due to poor connection of the walls of the first floor with those of the second. In this failure mechanism the mezzanine breaks the main walls almost horizontally, generating the instability of the second floor. This type of failure occurred in homes in the historic center of Chietla, but the buildings could not be observed because they collapsed. Other constructive problems that favored the destructive action of the earthquake are the following:

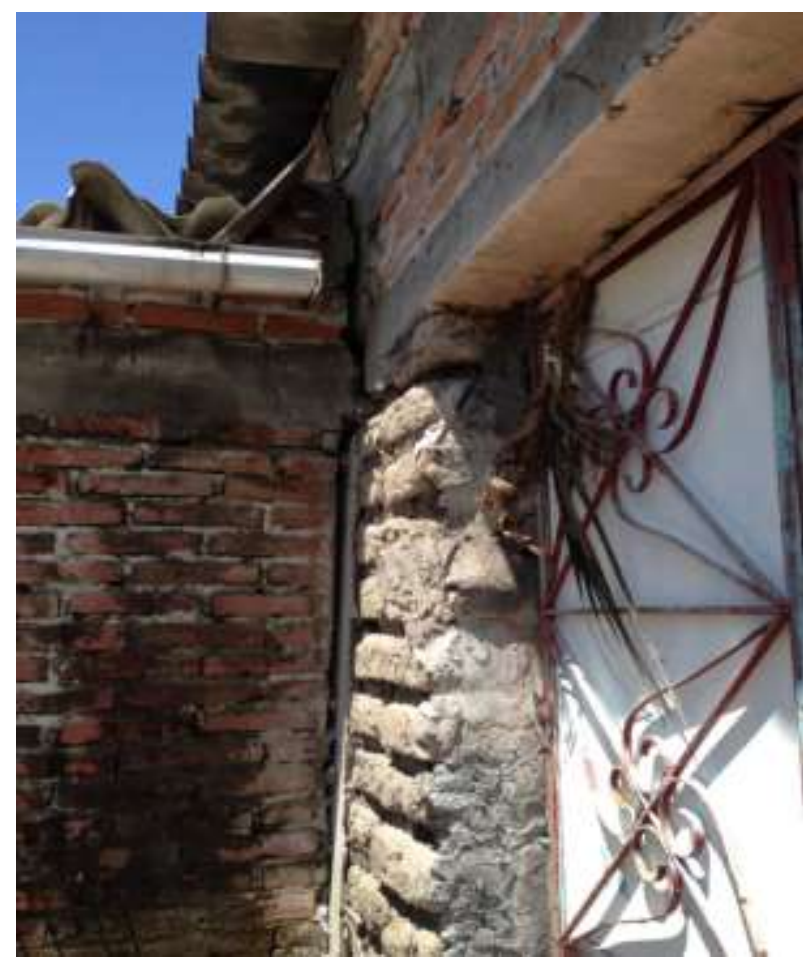

Figure 13 One of the problems encountered is that adobe dwellings are integrated with reinforced concrete frames and covered with reinforced concrete or ribbed asbestos Source: Faculty of Architecture BUAP, 2017

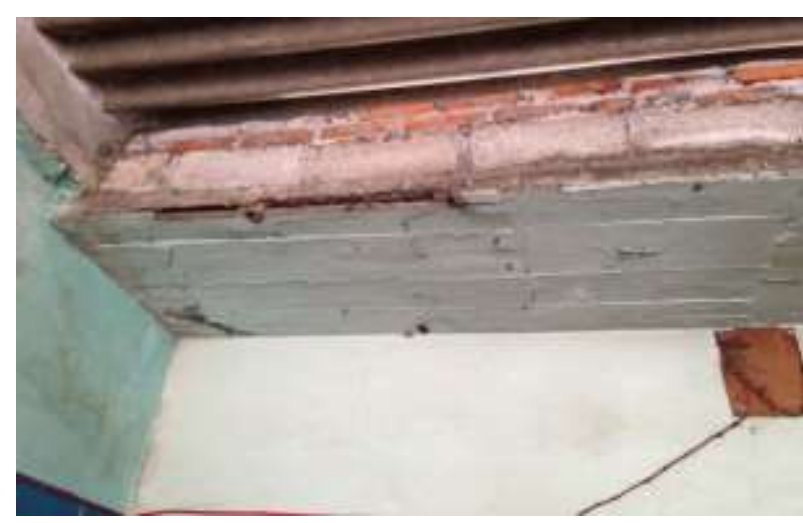

Figure 14 Interior view of the house of the image where reinforced concrete frames are integrated and rooms are added with other materials without taking care of the joints between one system and another

Source: Faculty of Architecture BUAP, 2017
VÁZQUEZ-TORRES, María del Rayo, CASTILLO-REYES, Alberto Rosendo, MORALES-ORTEGA, José Alejandro and MONTERO-URRUSQUIETA, Rubén Ángel. Effects of the earthquake of September 19,2017, in homes, in the municipality of 


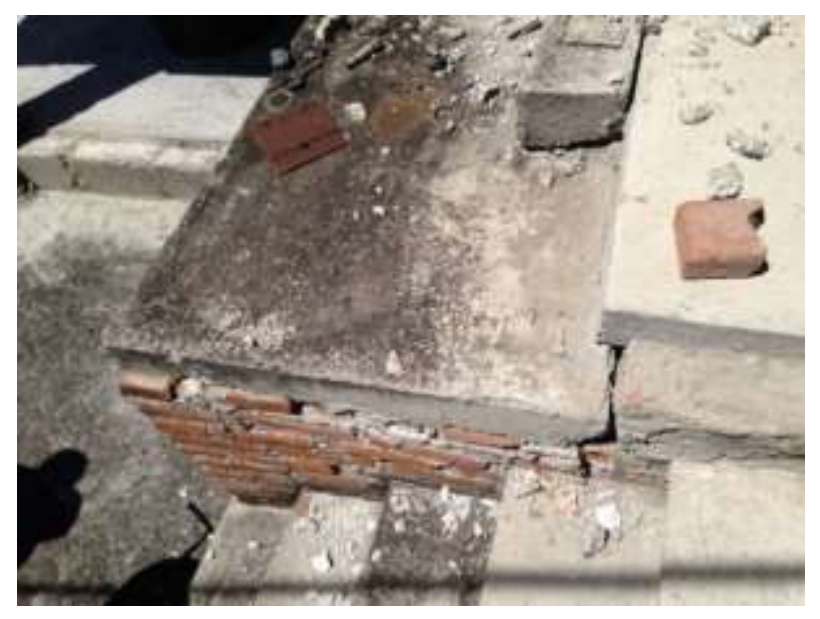

Figure 15 In several houses it was observed that the constructions of unconfined masonry were placed reinforced concrete roofs that caused separation between the slabs and compression in the walls

Source: Faculty of Architecture BUAP, 2017

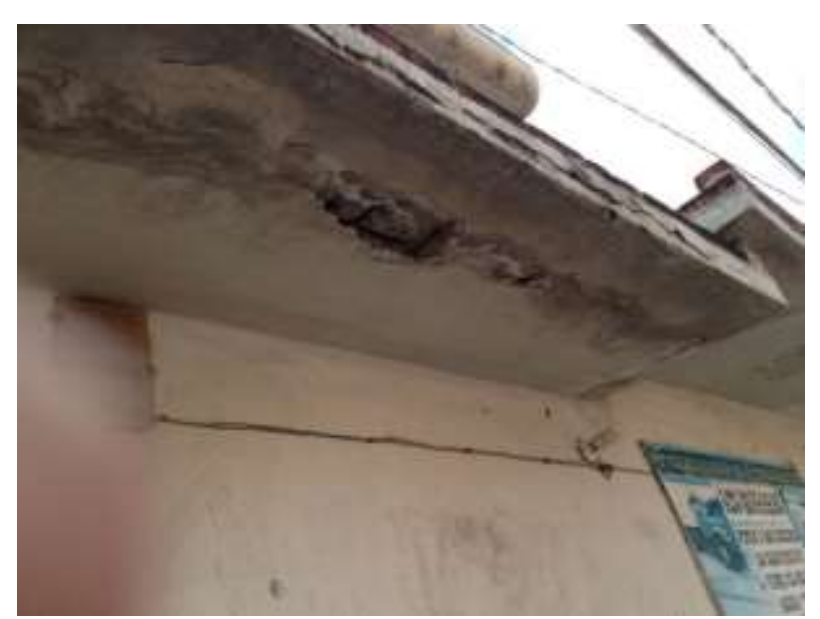

Figure 16 A common problem was that the eaves were too long and flexed causing cracks that moisture caused the degradation of the materials

Source: Faculty of Architecture BUAP, 2017

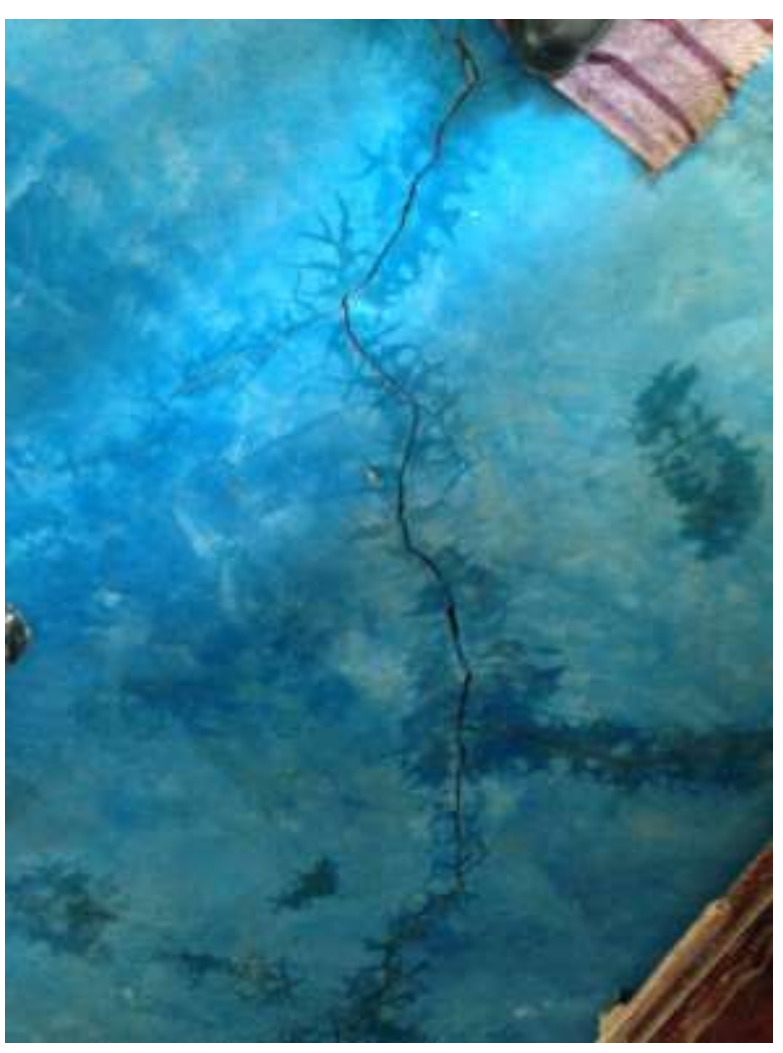

Figure 17 It was observed that there were already cracks produced by other earthquakes, in which the humidity caused more fissures than in the earthquake of 2017 were evidenced

Source: Faculty of Architecture BUAP, 2017
It is worth mentioning that of approximately 500 damaged homes in these analyses carried out, we have data that indicate the causes of the damage in this area, but what does not cease to be interesting, that the results indicate failures of the most common by the materials such as adobe, in the houses and buildings, not only by the construction system characteristic of these places, on the contrary it is more punctual than the cracks that appeared, were seen before the event so there was never a timely intervention, to avoid that in case of the eventualities to which this area is subjected, and the structural damage and failure in the adobe walls, which were of great magnitude, were minimized.

The quality of the houses and buildings, which were left to show that the minimum maintenance in the adobe walls, has not existed for a good time, this as mentioned above, leaves the house with the minimum security for its resistance, to the natural events that can be subjected, and that once the results are thrown forces us to generate, protocols that help us in a before and not after the damage caused by natural phenomena, because there are buildings that by the rains and seasons of ravaging, the adobe walls are degraded and never restored for their permanence, this makes them vulnerable to diverse situations, making them a danger to those who inhabit them.

On the other hand, the protocols to be proposed is of a constant technical supervision, which indicates the situation of the houses in a current way, to give indications to the inhabitants of the houses of how they should be observing their homes, since they are subjected to the constant volcanic activity and that this is often creating damage that in its beginnings is not visible until they are subjected to another type of detonating activity such as an earthquake and these collapse, creating irreparable damage, such as the loss of life, and that could well be avoided with the appropriate protocols for its mitigation of the damage caused.

\section{Conclusions}

The earthquake of September 19 called into question the concept of seismological danger, because the considerations that had been established for the disaster caused by the earthquakes, reminded us of the tragedy of September 19, 1985, which devastated part of Mexico City, and which was perceived in the state of Puebla.

VÁZQUEZ-TORRES, María del Rayo, CASTILLO-REYES, Alberto Rosendo, MORALES-ORTEGA, José Alejandro and MONTERO-URRUSQUIETA, Rubén Ángel. Effects of the earthquake of September 19, 2017, in homes, in the municipality of Chietla, Puebla. ECORFAN Journal-Spain. 2021 
In Puebla the earthquake of 7.1 degrees on September 19, 2017, left severe damage in the southern region of the state of Puebla, mainly in homes, hospitals, schools and the most serious in 620 buildings comprising temples and historic buildings.

In the case of Chietla, it is a town with a colonial historical center that was seriously affected by the old age of the materials and the weather conditions prior to the earthquake; in the case of the houses around the limits of the historic center they were affected by the inadequate way of using the construction systems, because these buildings are the product of unmanaged self-construction. However, it could be observed that adobe buildings had few problems, as they are the product of a great experience and constructive tradition that allow to build lasting and safe buildings.

\section{References}

ANZURES, Y. L. (19 de agosto de 2019). La Jornada de Oriente. Obtenido de La Jornada de Oriente:

https://www.lajornadadeoriente.com.mx/puebla /tiembla-atlixco-morelos/

Cano, Lidchy; Municipios; 13, febrero 2020; https://municipiospuebla.mx/nota/2020-0213/chietla/en-chietla-a\%C3\%BAn-hay-500casa-afectadas-por-el-sismo-de-2019

Carhuanira Herrera, W. E. (2021). Análisis de la vulnerabilidad sísmica de las viviendas informales de albañilería confinada Del Sector Aranjuez, Distrito De Trujillo, 2021.

CENAPRED, Centro Nacional de Prevención de desastres, Secretaría de Gobernación (8 de octubre de 2018). Calibración de datos de nubes de ceniza para los Volcanes Mexicanos. Obtained from: http://www1.cenapred.unam.mx/.../Ceniza/Acti vidad\%2031\%20Recopilación\%20de\%20pu...

CENAPRED, Centro Nacional de Prevención de desastres, Secretaría de Gobernación, Sismos, serie fascículos, 2011.

Espada Chilin, S. M., Mego Farías, A. S., Quevedo Rivera, H. F., Barreto Mauricio, R. J., \& Naupari Diaz, A. H. (2021). Procedimiento para una evaluación estructural en una vivienda de concreto armado.

Espíndola Víctor Hugo y Pérez Xyoli, ¿Qué son los sismos, dónde ocurren y cómo se miden? Revista Ciencia volumen 69 número 3 julioseptiembre, 2018
Gobierno del Estado de Puebla; Comisión estatal para la reconstrucción, informe sismo 19s recopilación sectorial de actividades en el proceso de reconstrucción de Puebla, 2018.

Gobierno del estado de Puebla, Programa Especial para Emergencias Sísmicas "Plan Sismo Puebla"2018

INAFED. (2018). Enciclopedia de los municipios y delegaciones. Obtained from: www.inafed.gob.mx > work > enciclopedia > municipios

Jaramillo, Juan Diego; Mecanismo de transmisión de cargas perpendiculares al plano del muro en muros de mampostería no reforzada, Revista de Ingeniería Sísmica No. 67 53-78 (2002).

López-Fuentes, N. I. G. A., Muñoz, M. A. T., \& Visoso, F. G. A. (2021). Estrés postraumático, ansiedad, afrontamiento y resiliencia en escolares tras el terremoto de 2017 en México. Psicología y Salud.

OMS. (2000). Fundamentos para la mitigación de desastres en establecimientos de salud. Washington, D.C: Organización Panamericana de la Salud Oficina Regional de la Organización Mundial de la Salud y Organización Mundial de la Salud.

Protección Civil. (1 de abril de 2019). Rutas de evacuación de Puebla transitables: Protección Civil. Obtained from: http://www.unionpuebla.mx

Ramírez, E., Montesinos, M., Morales, R., Uceda, S., Lourenço, P. B., \& Aguilar, R. (2015). Análisis mecánico de albañilería arqueológica de adobe bajo cargas de. Sevilla: 3er International conference on mechanical modelsin structuralengineering.

Secretaría de Seguridad y Protección Ciudadana y CENAPRED; Impacto socioeconómico de los principales desastres ocurridos en la República Mexicana; Secretaría de Seguridad y Protección Ciudadana; Centro Nacional de Prevención de Desastres; 2017

SSN Servicio sismológico nacional, http //www.ssn.unam.mx/

Varela Rivera, Chan Esquivel, Fernández Baqueiro y Moreno Herrera; comportamiento de muros de mampostería confinada con aberturas sujetos a cargas fuera del plano, Revista Concreto, cemento y desarrollo, Volumen no. 7; pág 52 a 65; Julio a diciembre 2015.

VÁZQUEZ-TORRES, María del Rayo, CASTILLO-REYES, Alberto Rosendo, MORALES-ORTEGA, José Alejandro and MONTERO-URRUSQUIETA, Rubén Ángel. Effects of the earthquake of September 19, 2017, in homes, in the municipality of Chietla, Puebla. ECORFAN Journal-Spain. 2021 
Silva, P. Y. F., \& Gálvez, D. M. (2021). Diferencias socioterritoriales en el conocimiento y uso de dispositivos ecológicos para la vivienda de la Ciudad de México. Estudios Demográficos y Urbanos.

Witer, J., Kress, V., \& Newhall, C. (2005). USGS CVO. Obtenido de Volcán Popocatépetl, México:

https://pubs.er.usgs.gov/publication/70027631

Yamín, L., Phillips, C., \& Reyes, J. (2007). Estudios de vulnerabilidad sísmica, rehabilitación y refuerzo de casas en adobe y tapia pisada. Revista Apuntes volumen 20, Número 2, 286-303. 